\title{
Preparation of Hydrophobic Monolithic Columns for On- line Solid-phase Extraction Coupled with HPLC for the Determination of Trace Level Benzo[a]pyrene
}

\section{Eser Miktardaki Benzo(a)piren Tayininde HPLC ile Birleştirilmiş On-line Katı-faz Özütlemesi için Hidrofobik Monolitik Kolonların Hazırlanması}

Research Article

Mehmet Emin Çorman ${ }^{1,2}$

'Department of Bioengineering, Sinop University, Sinop, Turkey.

'Department of Chemistry, Hacettepe University, Ankara, Turkey.

\begin{abstract}
A B STR AC T
Extraction of trace level persistent organic pollutants is an important issue in water samples. So in this work - p(HEMAPA) monolithic columns were developed as a novel kind of solid-phase extraction adsorbents, as well as $p$ (HEMAPA) solid-phase extraction (SPE) adsorbent was coupled with high-performance liquid chromatography (HPLC) ( $p$ (HEMAPA-HPLC) for the determination of benzo[a]pyrene (BaP) on-line mode. After p(HEMAPA-HPLC) parameters including the injection volume, flow rate, and the sample volume had been optimized in detail, BaP separation procedures on the $\mathrm{p}$ (HEMAPA-HPLC) containing mobile phase, different amounts of $\mathrm{BaP}$, and reusability were performed. Advantages of this procedure are low quantitation limits $(0.05-1.0 \mathrm{ng} / \mathrm{mL})$, short extraction time, low consumption of organic solvents, and ease of automation and operation of the whole analysis. The experimental results indicated that $\mathrm{p}$ (HEMAPA-HPLC) allowed for one-step BaPs extraction, clean-up and analytical determination under the optimal conditions. The reusability of BaPs from water samples was $99.7 \%$ with a negligible capacity decrease after ten adsorption-desorption cycles. The method detection limit (MDL), relative standard deviation (RSD) and recovery were obtained as $0.007 \mathrm{ng} / \mathrm{mL}, 0.26 \%$, and $97.0 \%$, respectively. It was concluded that $\mathrm{p}$ (HEMAPA) monolithic column coupled with HPLC was an excellent alternative for the routine analysis of BaPs at trace level.
\end{abstract}

\section{Key Words}

Monolithic column, High performance liquid chromatography, solid-phase extraction, benzo[a]pyrene.

\section{öz}

\begin{abstract}
F ser miktardaki kalıcı organik kirleticilerin su örneklerinde özütlemesi önemli bir konudur. Bu nedenle bu — çalışmada, yeni nesil katı-faz özütleme adsorbenti olarak p(HEMAPA) monolitik kolon geliştirilmiş, aynı zamanda, p(HEMAPA) katı-faz özütleme adsorbenti yüksek performanslı sıvı kromatografisi ile birleştirilerek p(HEMAPA-HPLC) on-line modda benzo(a)piren'in tayini gerçekleştirilmiştir. Enjeksiyon hacmi, akış hızı, ve örnek hacmi gibi HPLC parametreleri incelendikten sonra, ayırma işlemlerinde BaP derişimi, hareketli faz ve tekrar kullanılabilirlik çalışmaları gerçekleştirilmiştir. Bu yöntemin avantajları düşük tayin sınırı (0.05-1.0 ng/mL), kısa özütleme zamanı, düşük organik çözücü tüketimi ve tüm analiz boyunca çalışma ve otomasyonun kolay olmasıdır. Deneysel sonuçlar, optimum koşullar altında p(HEMAPA-HPLC) ile BaP özütlemesi, ayırımın ve analitik tayinin tek adıma gerçekleştiğini kanıtlamıştır. On kez ardı ardına tekrarlanan adsorpsiyon-desorpsiyon işlemi sonucunda adsorpsiyon kapasitelerinde önemli bir kayıp olmadan tekrar kullanılabilirlik \%99.7 olarak bulunmuştur. Yöntem tayin sınırı (MDL), standart sapma ve geri kazanım sırasıyla $0.007 \mathrm{ng} / \mathrm{mL}, \% 0.26$, and \%97, olarak hesaplanmıştır. HPLC ile birleştirilen p(HEMAPA) monolitik kolonun eser seviyedeki BaP'ın rutin analizi için mükemmel bir alternatif olduğu kanıtlanmıştır.
\end{abstract}

\section{Anahtar Kelimeler}

Monolitik kolon, yüksek performanslı sıvı kromatografisi, katı-faz özütleme, benzo(a)piren.

Article History: Received: Oct 5, 2016; Revised: Jan 15, 2017; Accepted: Feb 20, 2017; Available Online: Apr, 2017.

DOI: 10.15671/HJBC.2017.147

Correspondence to: M.E. Çorman, Sinop University, Department of Bioengineering, Sinop, Turkey. 


\section{INTRODUCTION}

Dolycyclic aromatic hydrocarbons (PAHs) are one of the most carcinogenic and stable organic compounds containing two or more fused aromatic rings [1]. They are usually formed by pyrolysis or incomplete combustion of organic materials during various industrial processes as well as natural processing and anthropogenic sources. PAHs are widely distributed and relocated in the atmosphere and subsequently into aquatic environments which result in the accumulation of toxic chemicals in soil, food, and water that lead to serious health problems and/ or genetic defects in humans [2-4]. Many of PAHs, especially benzo[a]pyrene (BaP) has attracted great attention as represent a significant risk to the humans $[5,6]$. Because of its high mutagenic and carcinogenic effects, it is frequently considered as a suitable marker of the presence of the PAHs in environmental contamination by the US Environmental Protectin Agency (EPA) $[7,8]$.

As a consequence, many methods have been developed for the rapid determination of $\mathrm{BaP}$ in water. The most common chromatographic techniques used for the quantification of BaPs are high-performance liquid chromatography (HPLC) with ultraviolet (UV) and/or fluorescence detection (FID) and gas chromatography with mass spectrometry (GC-MS). Although good results were obtained by these techniques, because of the complexity of particulates and low concentration of $\mathrm{BaP}$ in the environment, enrichment and clean-up procedures are required before the determination of $\mathrm{BaP}$ by analytical techniques. Many extraction methods which involve liquid-liquid extraction (LLE), liquid-liquid microextraction (LLME), solid-phase extraction (SPME), solid-phase microextraction (MSPE) have been applied to the extraction of BaPs [9]. Conventional LLE and SPE require a large volume of sample and hazardous organic solvents, timeconsuming besides being tedious. On the other hand, LLME and SPME have been proposed to alternative conventional LLE and SPE, but long extraction time and high costing are some of the disadvantages of these methods [10]. In fact, traditional PAHs determination methods have multi-step procedures that result in analyte loss during the process, complicated and require the use of organic solvents [11,12]. In this purpose, a new methodology has been developed to overcome this problem. The attention was focused on "On-line" methods which combine SPE to LC that has provided a new approach for extraction and determination of PAHs in a single step. $\mathrm{C}_{18}$-octadecyl is most widely used for the PAHs determination, while a variety of polymerbased matrices have proven to be used for SPE of adsorbed PAHs [13]. However, packed-bed columns present inherent diffusional limitations such as the slow diffusional mass transfer and the large void volume between the beads that result in low productivity [14].

Due to these limitations, different materials have been developed as alternative stationary phases in the separation science. Monolith materials have been considered with the aim of developing efficient, high selective and sensitive separation procedures. Monolith, because of their easy preparations, excellent flow properties, and high performances was used as SPE adsorbent for preconcentration of PAHs [15]. Several advantages of monoliths such as large surface area, short diffusion path, low-pressure drop, and very short residence time for both adsorption and elution have made the monolith potential adsorbent for the removal of toxic substances from water samples [16].

In this study, a hydrophobic monolithic column of poly(2-hydroxyethyl methacrylate- $\mathrm{N}$ methacryloyl-L-phenylalanine) (pHEMAPA) was synthesized in stainless steel HPLC columns (20 $\mathrm{cm} \times 5 \mathrm{~mm}$ id) using 2-hydroxyethyl methacrylate (HEMA) and N-methacryloyl-L-phenylalanine (MAPA) as monomers and ethylene glycol dimethacrylate (EGDMA) as crosslinker and used for developing a system by coupling monolith column with HPLC-FID. The results demonstrated that the monolithic column coupled with HPLC were applicable for the analysis of PAHs in water samples. Besides, the extremely low concentration of BaPs detected with $\mathrm{p}$ (HEMAPA-HPLC) as well as rapid analysis makes monoliths very attractive to be used in on-line extraction, enrichment, separation and detection of target molecules in one-step will lead to the development of very simple analytical methods. 


\section{MATERIALS and METHODS}

\section{Chemicals and Reagents}

Standards of PAHs including 1-naphthol, benzo(a) pyrene (BaP), benzo(b)fluoranthene $(\mathrm{BbF})$ benzo(k)fluoranthene $(B k F)$ and indeno $[1,2,3$ cd]pyrene (InPy) were of analytical grade and purchased from Aldrich (Milwaukee, WI, USA). Stock standard solutions of PAHs were dissolved in HPLC grade acetonitrile purchased from Caledon (Ontario, Canada). 2-Hydroxyethyl methacrylate (HEMA) and ethylene glycol methacrylate (EGDMA) were supplied from Fluka A.G. (Buchs, Switzerland). Potassium persulphate (KPS) and all of the other chemicals used were of reagent grade and obtained from MerckAG (Darmstadt, Germany). Barnstead (Dubuque, IA) Rop-ure LP ${ }^{\circledR}$ reverse osmosis unit with a high-flow cellulose acetate membrane (Barnstead D2731) followed by a Barnstead D3804NANo pure ${ }^{\circledR}$ organic/colloid removal and ion exchange packed-bed system were used to purify water. All solutions were stored at $4^{\circ} \mathrm{C}$ before analysis. $\mathrm{N}$-methacryloyl(L)-phenylalanine (MAPA) was chosen as a hydrophobic functional monomer.

\section{Chromatographic Equipment and Conditions}

Separation and detection of PAHs were performed by Shimadzu Prominence HPLC consisted of following components: a Model CBM-20A Lite control system unit; a Model LC-20AT pump consisted of an LPGE unit; a Model SIL-2OAHT automatic injection unit; a Model CTO-10ASVP column oven; a Model RF-20A fluorescence detector (excitation wavelength of $290 \mathrm{~nm}$ and emission wavelength of $430 \mathrm{~nm}$ ).

\section{Synthesis of SPE-HPLC (poly(2-hydroxyethyl methacrylate-N-methacryloyl-L-phenylalanine)- HPLC)}

The SPE-HPLC was synthesized by mixing the monomers, 2-hydroxyethyl methacrylate $(1 \mathrm{~mL})$ and $\mathrm{N}$-methacryloyl-L-phenylalanine $(200 \mu \mathrm{L})$ and crosslinker ethylene glycol methacrylate $(0.25 \mathrm{~mL})$ respectively, with $0.5 \mathrm{~m}$ of toluene as a pore former. The mixture was stirred at room temperature for $15 \mathrm{~min}$ and then KPS $(17 \mathrm{mg}$ ) was added to start the polymerization. This mixture was immediately poured into the stainless steel HPLC column $(20 \mathrm{~cm} \times 5 \mathrm{~mm}$ id) and heated at $75^{\circ} \mathrm{C}$ for $3.5 \mathrm{~h}$. After cooled to room temperature, the columns were connected with an HPLC pump and washed with deionized water and ethanol to remove unreacted monomers and porogenic diluents, and then rinsed with deionized water. The plain monolith was prepared using the same polymerization recipe without MAPA as a control.

\section{Characterization of SPE-HPLC Monoliths}

The bulk poly(2-hydroxyethyl methacrylate-Nmethacryloyl-L-phenylalanine) polymers were dried at room temperature and then crushed to small pieces, These polymers were used for the surface morphology, FT-IR, and elemental analysis. The surface morphology of the porous monolithic materials was investigated using a JEOL JSM6300 surface electron microscope. Elemental analysis was determined in an LECO CHNS-932 Analyser. FT-IR spectra were collected using Fourier transform infrared spectrophotometer (FTIR, 8000 Series, Shimadzu, Japan).

\section{On-Line Solid Phase Extraction by SPE-HPLC}

Extraction monolith was directly connected with the HPLC system. Online SPE-HPLC consisted of two steps, i.e., extraction and desorption. During extraction sample solution flowed through the extraction monolith by a pump at a rate of 1.0 $\mathrm{mL} \cdot \mathrm{min}^{-1}$, the temperature was kept at $40^{\circ} \mathrm{C}$, injection volume was $20 \mu \mathrm{L}$, and further using the fluorescence detector for excitation at 290 $\mathrm{nm}$ and emission greater than $430 \mathrm{~nm}$. The separation of PAHs was obtained by the following gradient program: $0-4$ min $\mathrm{CH}_{3} \mathrm{CN}-\mathrm{H}_{2} \mathrm{O}$ (100:0); 4.00-4.30 min from $\mathrm{CH}_{3} \mathrm{CN}-\mathrm{H}_{2} \mathrm{O}(100: 0)$ to $\mathrm{CH}_{3} \mathrm{CN}-$ $\mathrm{H}_{2} \mathrm{O}$ (80:20); 4.30-7.30 min $\mathrm{CH}_{3} \mathrm{CN}-\mathrm{H}_{2} \mathrm{O}$ (80:20). After finishing extraction, desorption step was obtained following gradient program: 7.30-8.00 min from $\mathrm{CH}_{3} \mathrm{CN}-\mathrm{H}_{2} \mathrm{O}$ (80:20) to $\mathrm{CH}_{3} \mathrm{CN}-\mathrm{H}_{2} \mathrm{O}$ (10:90); 8.00-18.00 min $\mathrm{CH}_{3} \mathrm{CN}-\mathrm{H}_{2} \mathrm{O}$ (10:90); 18.00-22.30 min $\mathrm{CH}_{3} \mathrm{CN}-\mathrm{H}_{2} \mathrm{O}$ (100: 0). At these conditions, the extraction and desorption were accomplished within $22.30 \mathrm{~min}$.

Stock solutions of PAHs were prepared at concentrations of $1 \mu \mathrm{g} . \mathrm{L}^{-1}$ with $\mathrm{CH}_{3} \mathrm{CN}-\mathrm{H}_{2} \mathrm{O}$ (90: 10). Extraction parameters including initial $\mathrm{BaP}$ concentration (0.05-10), mobile phase effect (ACN: $\mathrm{H}_{2} \mathrm{O}$ (50:50; 60:40; 70:30; 80:20; 90:10) and reusability were investigated and optimized. 


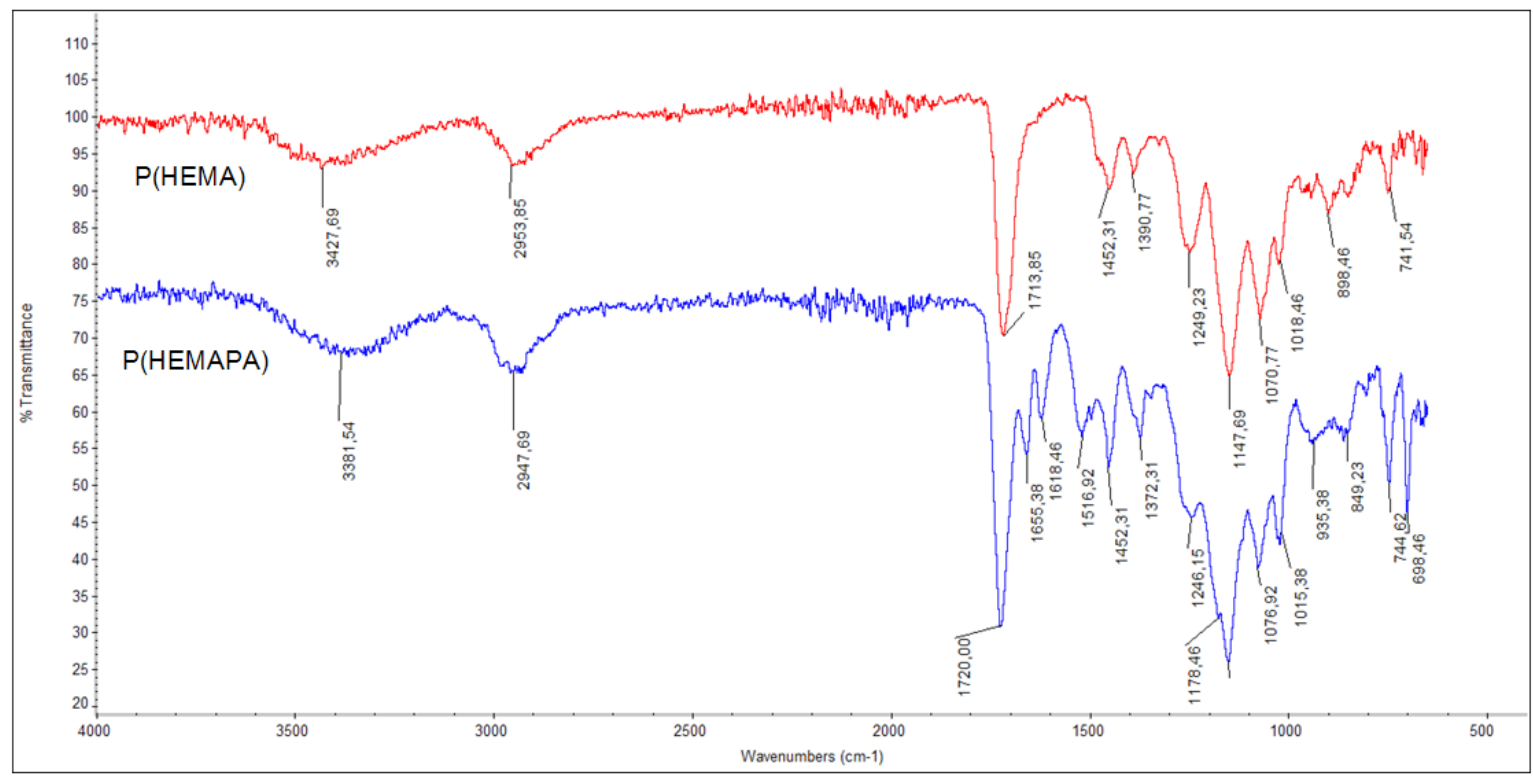

Figure 1. FTIR spectrums of monolithic columns.

All experiments $(n=3)$ and measurements $(n=3)$ were performed in triplicate.

\section{RESULTS and DISCUSSION}

\section{Characterization Studies}

The monomers selection plays the key role in determining the final selectivity and binding capacity of these monolithic columns. In this study, the hydrophobic environment was created in the polymeric matrix to bind a target molecule, for this purpose, N-methacryloyl-L-phenylalanine (MAPA) was chosen as the hydrophobic monomer that has some functional moiety with BAP as a target molecule.

The incorporation of MAPA within (HEMAPA) monolith was confirmed by the FTIR spectroscopy. Figure 1 showed the FTIR spectra of the $p$ (HEMA) and $p($ HEMAPA) monoliths. The different peaks at $1658 \mathrm{~cm}^{-1}$ ve $1618 \mathrm{~cm}^{-1}$ confirmed the presence of MAPA due to carbon-carbon stretching vibrations in the aromatic ring. Also, the bands observed at $3300 \mathrm{~cm}^{-1}, 2900 \mathrm{~cm}^{-1}$ and $1700 \mathrm{~cm}^{-1}$ indicated $-\mathrm{OH}$ stretching, $-\mathrm{CH}$ stretching and $-\mathrm{CO}$ stretching respectively, were originated from HEMA monomer.

The amount of MAPA incorporated onto p(HEMAPA) monolith surface was determined from the data by considering the nitrogen stoichiometry, which was found as $243.6 \mu \mathrm{mol}$ of
MAPA /g of polymer.

As shown by SEM image (Figure 2), the monolith is a highly porous polymer with large interconnected continuous walls ranging in size from 10 to $100 \mu \mathrm{m}$. It can be clearly observed that the surfaces of the pore walls are smooth.

\section{Bap Adsorption from Aqueous Solutions}

\section{Effect of Mobile Phase}

To control peak tailing due to interactions between the analyte and hydrophobic nature of column wall, mobile phase should be considered. Acetonitrile and water $\left(\mathrm{ACN}, \mathrm{H}_{2} \mathrm{O}\right)$ were studied for an efficiency separation of BaP in the mobile phase for this purpose. Following composition of mobile phase was contained $\mathrm{ACN}: \mathrm{H}_{2} \mathrm{O}$ (50:50; $60: 40 ; 70: 30 ; 80: 20 ; 90: 10)$. The increasing of ACN amount in the mobile phase improved peak shape and facilitated the separation (Figure 3). The peak tailing of $\mathrm{BaP}$ in improved greatly and the retention time was changed using $A C N$ : $\mathrm{H}_{2} \mathrm{O}$ in the ratio of 90:10. Additionally, altering the composition of $\mathrm{ACN}$ on $\mathrm{H}_{2} \mathrm{O}$ was markedly reduced the retention time from 12.19 to $9.96 \mathrm{~min}$ and proved efficient retention on the monolithic column to allow for separation of the template. As a result, the good separation was achieved by using these mobile phase composition. 


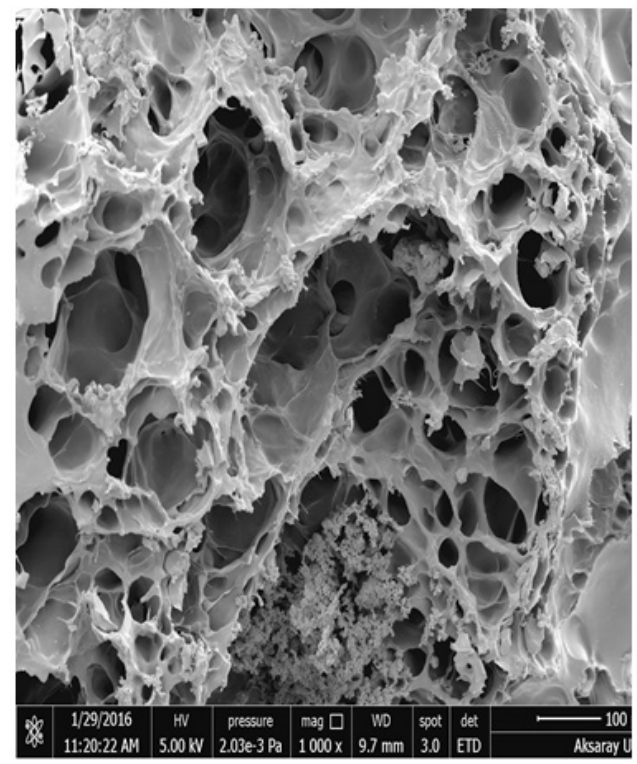

$\mathbf{A}$

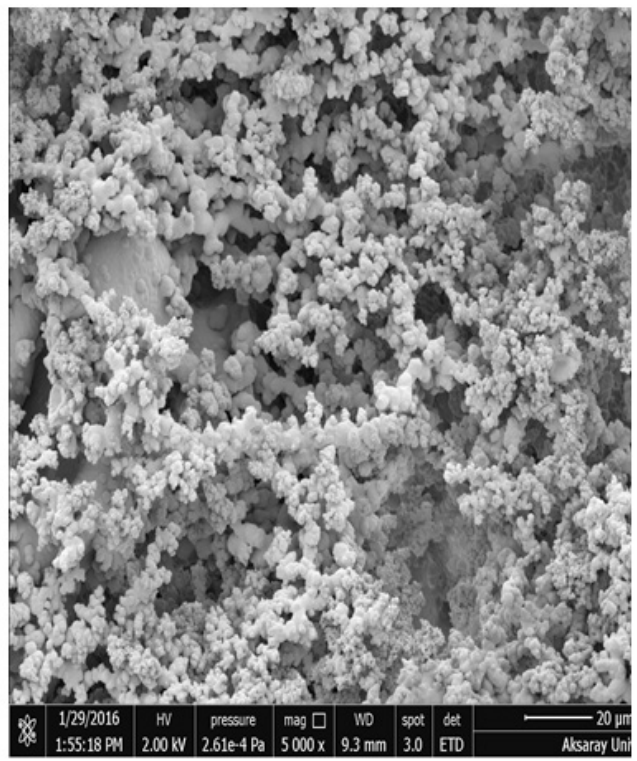

Figure 2. SEM photographs of (A) $p($ HEMA), and (B) p(HEMAPA) monolithic columns.

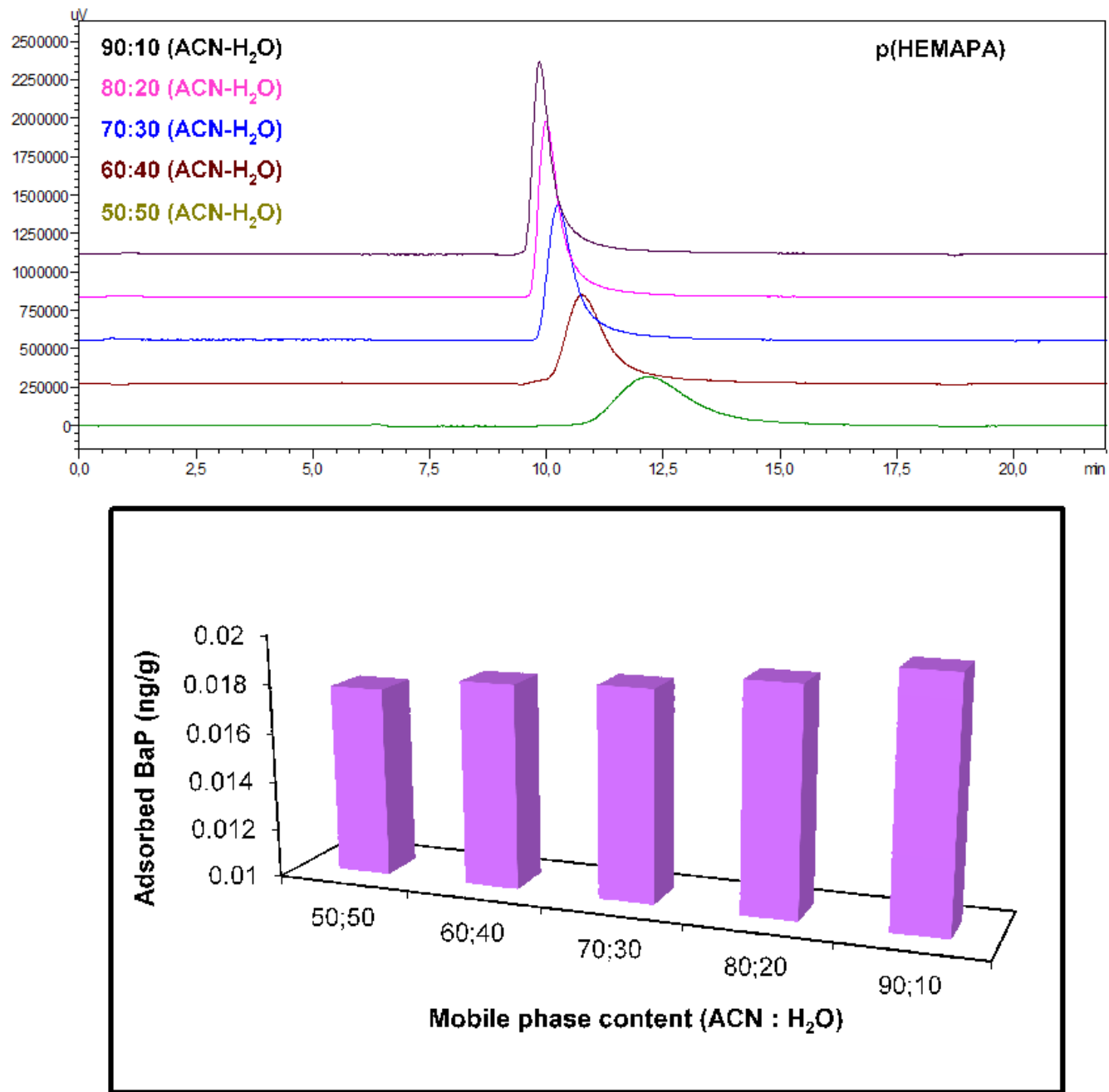

Figure 3. Effect of mobile phase content on BaP adsorption onto the monolithic columns. BaP concentration: $0.1 \mathrm{ng} / \mathrm{mL}$. HPLC conditions: flow rate: $1.0 \mathrm{~mL} / \mathrm{min}$; temperature: $40^{\circ} \mathrm{C}$; injection volume: $20 \mu \mathrm{L}$. 

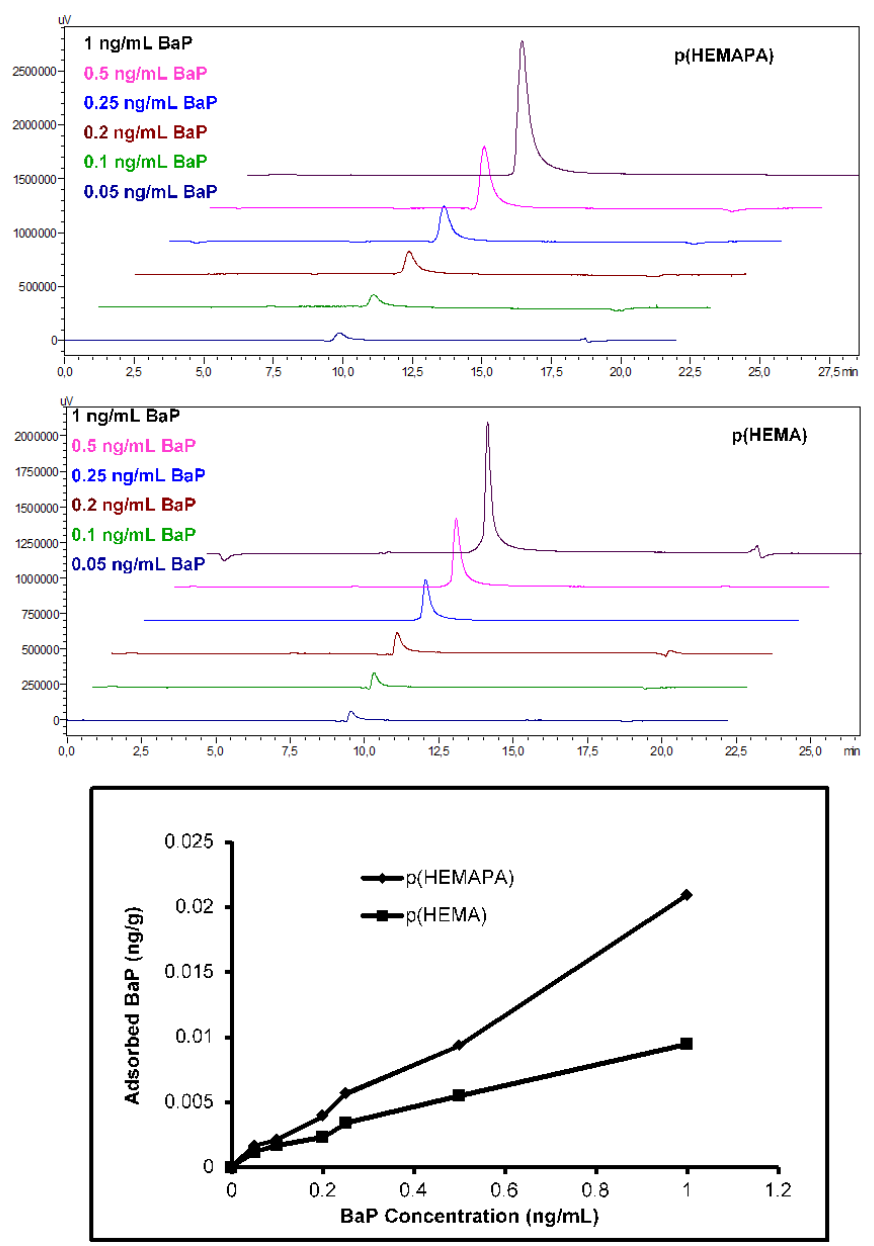

Figure 4. Effect of BaP concentration onto the monolithic columns. HPLC conditions: mobile phase: acetonitrile:water (90:10); flow rate: $1.0 \mathrm{~mL} / \mathrm{min}$; temperature: $40^{\circ} \mathrm{C}$; injection volume: $20 \mu \mathrm{L}$.

\section{Effect of Initial Concentration}

To further demonstrate the effect of initial concentration of BAP on adsorption, the adsorption of the BaP molecules onto SPE-HPLC was carried out by different concentrations from $0.05 \mathrm{ng} / \mathrm{mL}$ to $1.0 \mathrm{ng} / \mathrm{mL}$. The concentration of BaP was chosen according to U.S. Environmental Protection Agency (EPA) that was reported as $0.2 \mathrm{ng} / \mathrm{mL}$ for maximum toxicity level [17]. As shown in Figure 4, it is clear that the amounts of $\mathrm{BaP}$ adsorbed onto $\mathrm{p}$ (HEMAPA) monolith and the peak area of BaP increased substantially with increasing BAP initial concentration.

Although $\mathrm{p}(\mathrm{HEMA})$ monoliths displayed similar trend to $\mathrm{p}$ (HEMAPA) monolith on the PAHs adsorption, as seen in Figure 4, their adsorption capacity was relatively lower as $0.009 \mathrm{ng} / \mathrm{g}$ that may be because of the non-specific adsorption of $p(H E M A)$ monolith. The results indicated that specific adsorption was performed by specific non-covalent interactions between MAPA functional monomer and BAP i.e. the hydrophobic interactions and $\pi-\pi$ interactions resulted from the aromatic ring structure of BaP and thus they produced higher adsorption capacity. Besides, rapid adsorption of $\mathrm{BaP}$ onto the $\mathrm{p}(\mathrm{HEMA})$ and p(HEMAPA) monoliths was achieved as about 9 $\min$.

Interestingly, the results showed that $\mathrm{BaP}$ was detected in the range of $0.05 \mathrm{ng} / \mathrm{mL}$ to $1.0 \mathrm{ng} /$ $\mathrm{mL}$ and the minimum concentration of $\mathrm{BaP}(0.2$ $\mathrm{ng} / \mathrm{mL}$ ) was detected in water samples. Based on these results, the maximum of sensitivity for the detection of BaP was achieved as $0.05 \mathrm{ng} /$ $\mathrm{mL}$. In the application of the technique to the environmental samples, monoliths should allow for the determination of PAH compounds. 

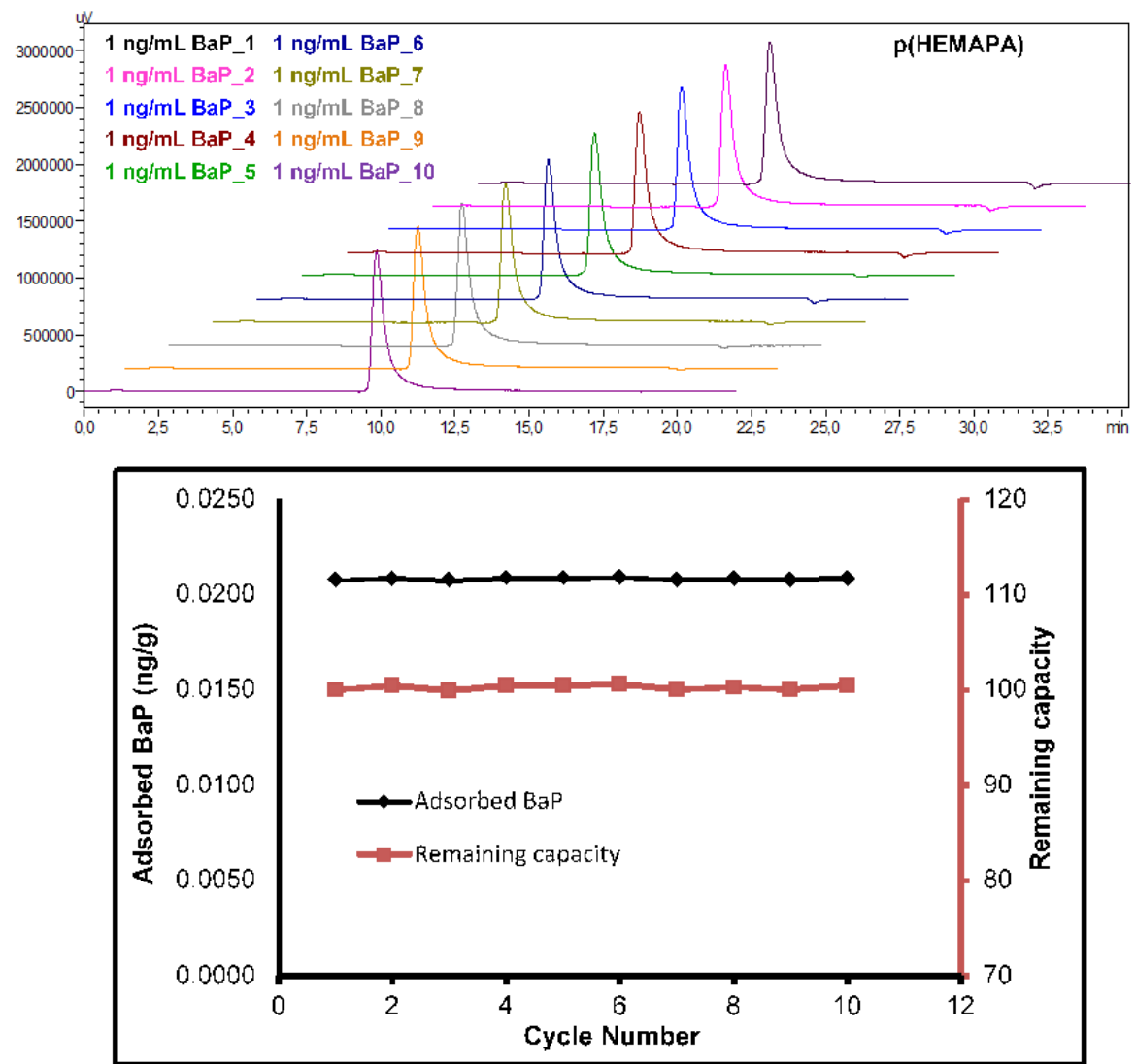

Figure 5. Reusability of the BaP-MIP-2, NIP and blank composite monoliths. BaP concentration: $0.1 \mathrm{ng} / \mathrm{mL}$. HPLC conditions: flow rate: $1.0 \mathrm{~mL} / \mathrm{min}$; temperature: $40^{\circ} \mathrm{C}$; injection volume: $20 \mu \mathrm{L}$.

\section{Evaluation of Adsorption Isotherm}

To determine the equilibrium adsorption of BaP onto the monolithic column, the obtained data was fitted notable adsorption isotherms such as Langmuir and Freundlich. The Freundlich adsorption model refers to heterogeneous systems, which primarily organic compounds or highly interactive species are adsorbed onto the heterogeneous surface [18]. The Langmuir and Freundlich isotherms are represented by Equatins (1) and (2), respectively. From the data in Table 1, that value of $1 / \mathrm{n}=0.981$ while $K_{F}=2.36 \mathrm{x}$ $10^{-5}$ indicating that the sorption of $\mathrm{BaP}$ onto SPEHPLC is favorable and the $R^{2}$ value is 0.999. These data often fit the empirical equation proposed by Freundlich.

$q=q_{\max } \cdot b \cdot C e q /\left(1+b \cdot C_{e q}\right)$

$q=K_{F} \cdot C_{\mathrm{eq}}{ }^{1 / n}$

where $\mathrm{q}$ is the adsorbed amount of the target molecules ( $\mathrm{ng} / \mathrm{g}), \mathrm{q}_{\max }$ is the maximum adsorption capacity $(\mathrm{ng} / \mathrm{g}), \mathrm{C}_{\text {eq }}$ is the equilibrium target molecule concentration in solution $(\mathrm{ng} / \mathrm{mL}), b$ is the constant eluted to the affinity binding sites, $K_{F}$ is the Freundlich constant, and $\mathrm{n}$ is the Freundlich exponent.

\section{Monolithic Column Reusability}

To investigate the efficiency of coupling monolithic column to HPLC and the reusability of the composite column, adsorption-desorption cycles were successively repeated 10 times by using the same monolithic column under the optimal experimental conditions. The reusability of the monolithic columns was calculated as $99.7 \%$ (Figure 5). Furthermore, the method detection limit (MDL), relative standard deviation (RSD) and recovery values were calculated as 0.007 $\mathrm{ng} / \mathrm{mL}, 0.26 \%$, and $97.0 \%$, respectively The results indicated that the developed composite monolithic column could be used in combination with HPLC and suitable detection as a reusable, efficient, and cost-effective alternative for extraction of PAH from water samples. 


\section{CONCLUSION}

A novel material of $p$ (HEMAPA) hydrophobic monolithic column was developed as a trace analytical method based on SPE-HPLC to extract PAHs from water samples, presenting robust extraction capacity for PAHs. The concept of using monolithic column conducted in stainless steel HPLC columns is that its fast mass transfer, large specific surface areas, and high adsorption capacity allow separation of desired molecules in a complex water environment. It will skip the clean-up and enrichment procedures required prior analysis in off-line modes, and enable online modes which couple SPE preconcentration step to HPLC sensitive separation of the desired molecule from crude samples. The results showed that $\mathrm{p}$ (HEMAPA) was an excellent adsorbent to enrich PAHs from water sample because of its highly hydrophobic characteristic and unique structure with interconnected pores. The combining of SPE with HPLC provided selective and sensitive analysis of PAHs at very low levels in aqueous media. The maximum sensitivity for the detection of BaP was achieved as $0.05 \mathrm{ng} / \mathrm{mL}$ with well-separated peaks with an analysis time of $12 \mathrm{~min}$. It can be concluded that the proposed method could be applied for the routine analysis of the PAHs in the analysis of water samples.

\section{ACKNOWLEDGEMENT}

I acknowledge The Scientific and Technological Research Council of Turkey with a grant number as TUBITAK-KBAG$214 Z 236$ for funding this work. The author is thankful to Hacettepe University BIOREG Research Group, Sinop University Faculty of Engineering and Architecture respectively for providing research fellowships.

\section{References}

1. S. Moret, G. Purcaro, L.S. Conte, Polycyclic aromatic hydrocarbons (PAHs) levels in propolis and propolisbased dietary supplements from the Italian market, Food Chem., 122 (2010) 333-338.

2. S. Moret, L.S. Conte, Polycyclic aromatic hydrocarbons in edible fats and oils: occurrence and analytical methods, J. Chromatogr. A, 882 (2000) 245-253.

3. N. Ozaki, Y. Takamura, K. Kojima, T. Kindaichi, Loading and removal of PAHs in a wastewater treatment plant in a separated sewer system, Water Res., 80 (2015) 337-345.
4. S.A. Tfouni, R. Machado, M.C. Camargo, S.H. Vitorino, E. Vicente, M.C.F. Toledo, Determination of polycyclic aromatic hydrocarbons in cachaça by HPLC with fluorescence detection, Food Chem., 101 (2007) 334338.

5. S. Shariati-Feizabadi, Y. Yamini, N. Bahramifar, Headspace solvent microextraction and gas chromatographic determination of some polycyclic aromatic hydrocarbons in water samples, Anal. Chim. Acta, 489 (2003) 21-31.

6. N. Kishikawa, M. Wada, N. Kuroda, S. Akiyama, K. Nakashima, Determination of polycyclic aromatic hydrocarbons in milk samples by high-performance liquid chromatography with fluorescence detection, J. Chromatogr. B, 789 (2003) 257-264.

7. K. Dost, C. Ideli, Determination of polycyclic aromatic hydrocarbons in edible oils and barbecued food by HPLC/UV-Vis detection, Food Chem., 133 (2012) 193199.

8. R. Goldman, L. Enewold, E. Pellizzari, J.B. Beach, E.D. Bowman, S.S. Krishnan, P.G. Shields, Smoking increases carcinogenic polycyclic aromatic hydrocarbons in human lung tissue, Cancer Res., 61 (2001) 6367-6371.

9. K. Li, H. Li, L. Liu, Y. Hashi, T. Maeda, J.-M. Lin, Solidphase extraction with $\mathrm{C} 30$ bonded silica for analysis of polycyclic aromatic hydrocarbons in airborne particulate matters by gas chromatography-mass spectrometry, J. Chromatogr. A, 1154 (2007) 74-80.

10. J. Ma, R. Xiao, J. Li, J. Yu, Y. Zhang, L. Chen, Determination of 16 polycyclic aromatic hydrocarbons in environmental water samples by solid-phase extraction using multi-walled carbon nanotubes as adsorbent coupled with gas chromatography-mass spectrometry, J. Chromatogr. A, 1217 (2010) 54625469.

11. M.F. Alpendurada, Solid-phase micro extraction: a promising technique for sample preparation in environmental analysis, J. Chromatogr. A, 889 (2000) 3-14.

12. A. King, J. Readman, J. Zhou, Determination of polycyclic aromatic hydrocarbons in water by solidphase microextraction-gas chromatography-mass spectrometry, Anal. Chim. Acta, 523 (2004) 259-267.

13. W.D. Wang, Y.M. Huang, W.Q. Shu, J. Cao, Multiwalled carbon nanotubes as adsorbents of solid-phase extraction for determination of polycyclic aromatic hydrocarbons in environmental waters coupled with high-performance liquid chromatography, J. Chromatogr. A, 1173 (2007) 27-36.

14. L. Uzun, R. Say, A. Denizli, Porous poly (hydroxyethyl methacrylate) based monolith as a new adsorbent for affinity chromatography, React. Funct. Polym., 64 (2005) 93-102.

15. X. Guan, C. Zhao, X. Liu, H. Zhang, Hyperbranched polymers containing stereocontorted cores as online solid-phase microextraction adsorbent for polycyclic aromatic hydrocarbons, J. Chromatogr. A, 1302 (2013) 28-33.

16. L. Uzun, D. Türkmen, E. Yılmaz, S. Bektaş, A. Denizli, Cysteine functionalized poly (hydroxyethyl methacrylate) monolith for heavy metal removal, Colloids and Surfaces A: Physicochemical and Engineering Aspects, 330 (2008) 161-167. 
17. H.I. Abdel-Shafy, M.S. Mansour, A review on polycyclic aromatic hydrocarbons: source, environmental impact, effect on human health and remediation, Egyptian Journal of Petroleum, 25 (2016) 107-123.
18. K. Foo, B. Hameed, Insights into the modeling of adsorption isotherm systems, Chem. Eng. J., 156 (2010) 2-10. 
